\title{
Reorientasi Nilai Sufisme Individual-Transedental Dalam Naskah at Tuhfah al Mursalah Menuju Sosio-Empirik
}

\author{
Ihsan Sa'dudin
}

Universitas Jenderal Soedirman, Purwokerto

sadudiinisan@gmail.com

\begin{abstract}
The manuscript at-Tuhfah al-Mursalah as a track record of the past is full of virtues. Seeking virtue means preparing yourself through the purification process. Sufism, as a purification step to reach the Most Holy One. The spiritual experience gained by Salik when meeting and union with God (individual-transcendental values) should be felt also by others. The transmission of spiritual experience is implemented in empirical life (socio-empirical values) as a form of practicing and teaching the teachings of a loving Islam, so that the concept of rahmatan lil 'alamin can be felt by all creatures. The process of attaining the maqam requires clarity of heart; peace of mind, mind and environment; as well as sincerity amaliyah. Awareness to negate the existence of self ('alam nasut) and purify the existence of divinity ('alam lahut) in self as a form of preparation to accept the holiness of the Khaliq. It is this doctrine of purity that should be practiced and spread by the salik and perceived by all beings to create goodness in the universe.Goodness that does not look to ethnic, religious, ethnic, and state boundaries.Universal goodness as the real essence of Islam rahmatan lil a'lamin
\end{abstract}

Keywords: Sufism,Manuscript, Individual-transcendental values, Socio-empirical

\begin{abstract}
Abstrak
Naskah at-Tuhfah al-Mursalah sebagai rekam jejak masa lalu yang sarat akan nilai kebajikan. Mencari kabajikan berarti menyiapkan diri melalui proses penyucian. Tasawuf, sebagai langkah menyucikan diri untuk mencapai Sang Maha Suci. Pengalaman spiritual yang didapatkan oleh salik ketika berjumpa dan bersatu diri dengan Tuhan (nilai-nilai individual-transedental) hendaknya dirasakan juga oleh yang lain. Penularan pengalaman spiritual diimplementasikan dalam kehidupan empirik (nilai-nilai sosio-empirik) sebagai bentuk pengamalan dan pengajaran ajaran islam yang penuh cinta kasih, sehingga konsep rahmatan lil 'alamin dapat dirasakan oleh segenap makhluk. Proses untuk mencapai maqam tersebut membutuhkan kejernihan hati; ketenangan jiwa, pikiran, dan lingkungan; serta kesungguhan amaliyah. Kesadaran untuk menegasikan eksistensi diri (alam nasut) dan menyucikan eksistensi ketuhanan (alam lahut) dalam diri sebagai bentuk persiapan menerima kesucian Sang Khaliq. Ajaran kesucian ini lah yang hendaknya diamalkan dan ditebarkan oleh salik serta dirasakan oleh seluruh makhluk sehingga tercipta kebaikan di semesta alam. Kebaikan yang tidak memandang suku, agama, etnis, dan batas negara. Kebaikan universal sebagai hakikat nyata Islam rahmatan lil a'lamin.
\end{abstract}

Kata kunci: Sufisme, Naskah, Nilai Individual-transedental, Nilai sosio-empirik 


\section{A. Pendahuluan}

Hakikat ajaran agama Islam adalah mengajarkan kesalehan baik secara lahir maupun batin kepada pemeluknya. Spesialisasi bidang keilmuan syariah mengajarkan umat Islam untuk hidup saleh lahiriyah, sedangkan ilmu tasawuf mengajarkan kesalehan batin. Kedua disiplin kelimuan tersebut tetap berpedoman pada al-Qur'an dan al-Hadis, akan tetapi ada perbedaan mendasar di antara keduanya. Ilmu syariah memiliki kecenderungan memilih fiqih dengan menggunakan rasio dan logika dalam memahami al-Qur'an dan alHadis sebagai sebuah ketetapan hukum. Sedangkan ilmu tasawuf memiliki kecenderungan menggunakan rasa (zauq) ketika mengamalkan al-Qur'an dan al-Hadis ${ }^{1}$. Sehingga dampak kesalehan yang dirasakan adalah kesalehan spiritual dan kesalehan sosial. Kesalehan spiritual ditandai dengan semakin bisa merasakan (zauq) kekhusuan dan kenikmatan beribadah kepada Allah tanpa adanya rasa lelah dan terbebani bahkan menjadi sebuah kebutuhan akan ibadah tersebut. Kesalehan selanjutnya adalah kesalehan sosial, pada tataran kehidupan sosial seorang sufi akan lebih bisa memaknai hidup sebagai sarana untuk mendekatkan diri kepada Allah. Dengan mengamalkan syariat dan amal saleh kepada sesama makhluk, mereka menggapai hakikat Yang Haq.

Dalam hal ini, perjalanan sufi dikatergorikan sempurna apabila dia sudah menegasikan dirinya sendiri dan mengafirmasikan eksistensi Tuhan, baik dalam bentuk ittihaad (penyatuan), hulul (inkarnasi), wahdatul wujud (kesatuan wujud), dan suasana mistik lainnya yang melampaui, mencakupi, dan menekan sesaat kepribadian privat pelaku pengalaman tersebut (individual-transedental). ${ }^{2}$ Kemudian, keadaan sufi dikategorikan lebih sempurna apabila dia menyadari dirinya sendiri sedang fana' bersama Tuhan. Dan selanjutnya perjalanan seorang sufi dikategorikan penyempurna ketika dia mengamalkan secara nyata di dunia ini (realitas) semua pengalaman yang dia dapatkan di dunia hakikat (sosial-empirik). Pengamalan ini berupa perjuangan sosial dari hubungan vertikal ke horisontal sebagai upaya membangun fisik, psikis, moral, dan kultural demi terjaganya perdamaian kehidupan secara individu dan sosial.

Batin atau rohani manusia merupakan hal yang tidak dapat dilihat, sehingga pemberian definisi terhadap ilmu yang mengkaji tentang hal itu (baca: tasawuf) sulit untuk didefinisikan. Akan tetapi, kesalehan batin ini dapat dilihat dari faktor- faktor yang hadir dalam ucapan, cara, dan sikap hidup para sufi. Sebuah definisi tasawuf hadir atas

${ }^{1}$ Alwan Khoiri, Integrasi Pengamalan Syari'ah dan Tasawuf, sebuah makalah yang disampaikan dalam Focused Group Discussion Pascasarjana UIN Sunan Kalijaga, 29 Desember 2014, hlm. 13.

${ }^{2}$ M. Saeed Sheikh, Rekonstruksi Pemikiran Religius dalam Islam, (Bandung: Mizan, 2016), hlm. 20. 
pengalaman kesufian yang dialami langsung oleh para sufi, sehingga definisi tasawuf beragam dan terkadang berbeda antara satu sufi dengan sufi lainnya. Pengertian tasawuf adalah pengertian yang muncul dari pengalaman. ${ }^{3}$ Seperti halnya Ibn 'Arabi mendifinisikan tasawuf sebagai proses pengaktualisasian potensi akhlak Allah (al- Haq) yang ada di dalam diri kita (manusia atau khalq), dan menjadikannya akhlak kita (attakhalluq bi khulqillah). ${ }^{4}$

Kata sufi secara etimologi memiliki arti yang beragam, seperti ada teori yang mengatakan kata sufi bermakna kain wol kasar, karena pada masa sahabat kain wol suka digunakan oleh orang-orang yang mempunyai kesalehan zuhud dan lambang kesederhanaan. Al- Junaid memberikan definisi tasawuf sebagai sebuah sikap yang harus dijalani sufi dengan cara menyucikan hati sehingga tidak ditimpa suatu kelemahan, menjauhi akhlak alami, melenyapkan sifat kemanusiaan, dan menjauhi segala keinginan nafsu. ${ }^{5}$ Tasawuf sebagai bentuk usaha melatih jiwa (mujahadah) yang dilakukan seorang hamba dengan sungguh-sungguh sehingga dapat membebaskan dirinya dari pengaruh kehidupan dunia untuk mendekatkan diri kepada Allah, jiwanya menjadi bersih, berakhlak mulia dalam kehidupannya, dan menemukan kebahagiaan spiritual.

Akhlak mulia bersumber dari keyakinan hati (aspek bathin) yang kuat. Sebagaimana Rasulullah yang sudah menguasai batinnya dengan sangat kuat sehingga jiwanya terbentuk, kuat dalam menghadapi kesukaran dan siksaan dari musuh, kuat dalam kekurangan, kuat dalam menguasai diri menjadi seorang yang paling mulia dalam tindakan serta ucapan, dan kuat dalam berbagai hal lainnya. Rasulullah memberikan uswah hasanah dengan menjadikan hidup kerohanian sebagai sendi kekuatan batin. ${ }^{6}$ Pola hidup seperti itu terus berlanjut pada masa sahabat, tabi'in, dan ulama sufi sampai sekarang meskipun Rasulullah sudah menghadap Yang Kuasa. Sebuah kehidupan yang ditegakkan atas kemurnian jiwa dan kebersihan hati sebagai kekuatan batin.

Penjelasan di atas merupakan sebuah gambaran pembahasan dalam naskah atTuhfah al-Mursalah yang terdapat di Perpustakaan Masjid Agung Keraton Surakarta. Naskah ini berbahasa Arab dan beraksara Arab serta Jawa Pegon sebagai penjelasnya.

3 Muhammad Yunus Masrukhin, Biografi Ibn Arabi Perjalanan Spiritual Mencari Tuhan bersama Para Sufi, (Depok: Keira Publishing, 2015), hlm. 12.

4 Muhammad Yunus Masrukhin, Biografi Ibn Arabi Perjalanan Spiritual Mencari Tuhan bersama Para Sufi, (Depok: Keira Publishing, 2015), hlm. xii.

5 Ris'an Rusli, Tasawuf dan Tarekat Studi Pemikiran dan Pengalaman Sufi, (Jakarta: Rajawali Press, 2013), hlm. 7. Lihat juga Ibrahim Basuni, Nasy'ah al- Tasawuf al- Islami, (Mesir: Dar al- Ma'arif, 1919), hlm. 9.

6 Mustafa Zahri, Kunci Memahami Ilmu Tasawuf, (Surabaya: Bina Ilmu, 1995), hlm. 33. 


\section{B. Metode Penelitian}

Penelitian ini adalah penelitian kepustakaan atau libraryresearch, karena penelitian ini bersifat penelitian kualitatif. Jenis penelitian ini mengambil data- data berasal dari sumber- sumber kepustakaan baik berupa naskah, buku, dan hasil penelitian lainnya yang memiliki kesesuaian dengan topik kajian penelitian. ${ }^{7}$

Pada penelitian ini, peneliti menggunakan metode dokumentasi untuk mengumpulkan data, yaitu mengumpulkan data dengan menelaah laporan yang tersedia. ${ }^{8}$ Peneliti menelaah naskah at-Tuhfah al-Mursalah yang menjadi sumber data primer pada penelitian ini, kemudian membaca penelitian terdahulu tentang tasawuf. Kemudian datadata tersebut dianalisis untuk mendapatkan sebuah kesimpulan terhadap sasaran penelitian yang diharapkan.

Objek penelitian ini adalah naskah, sehingga peneliti menggunakan pendekatan filologi untuk mengkaji naskah tersebut.Terdapat beberapa alasan peneliti menjadikan naskah at-Tuhfah al-Mursalah sebagai objek penelitian ini, yaitu : (1) tema kajian naskah tersebut adalah tasawuf. Tema ini sebagai pokok- pokok keimanan dan keislaman setiap individu muslim, (2) naskah at-Tuhfah al-Mursalah memiliki konsep yang bermanfaat bagi masyarakat umum tentang hakikat diri. Karena problematika besar yang dihadapi manusia modern saat ini adalah ketidaktahuan akan hakikat dirinya sehingga terkadang timbul problematika sosial yang bersumber dari hal kecil, (3) naskah merupakan warisan rohani bangsa yang sangat penting dan berharga, mengingat kandungan naskah banyak memberikan nilai guna bagi masyarakat, baik secara pengetahuan ataupun spiritual sehingga perlu dijaga dan dilestarikan, (4) naskah at-Tuhfah al-Mursalah belum ada peneliti yang mengkaji.

Penelitian ini sebagai usaha penyelamatan naskah dari kemungkinan kepunahan, kemudian menyajikan hasilnya kepada khalayak masyarakat. Hal lainnya adalah karena pada masa kini tasawuf dituntut melakukan reorientasi dan tanggungjawab tidak hanya pada kesalihan individual serta moral, akan tetapi lebih jauh lagi pada kesalihan sosial sebagai bentuk perubahan dari jiwa kepada fisik, ruhani kepada jasmani, meditasi kepada tindakan nyata, dan dari nilai pasif kepada nilai aktif.

7 Dadang Abdu Rahman, Pengantar Metode Penelitian, (Yogyakarta: Kurnia Kalam Semesta, 2003), hlm.7.

8 Ahmad Tahzeh, Pengantar Metode Penelitian, (Yogyakarta: Teras, 2009), hlm. 66. 


\section{Hasil dan Pembahasan}

\section{Naskah at-Tuhfah al-Mursalah}

Naskah at-Tuhfah al-Mursalah adalah naskah yang menjelaskan pemikiran alSyaikh Muhammad ibn al-Syaikh Fadl Allah al-Hindi al-Buhanfuri (w. 1020 H/1620 M), seorang sufi-filsuf dari India yang mendapat pengaruh dari Ibn Arabi. Sehingga pemikiran Ibn Arabi memberikan pengaruh pada konsep tasawuf al-Buhanfuri, seperti Wujud, martabah tujuh, dan insan kamil.

\section{a. Wujud}

Seorang sufi yang ingin berada sedekat mungkin dengan Allah dan dapat menyatu dengan-Nya harus menempuh jalan panjang yang disebut dengan tempat-tempat pemberhentian atau tingkatan spiritual (maqamat). Maqamat ini meliputi cara seorang saalik menempuh jalan syariat, tarekat, hakikat, dan makrifat. Keempat aspek tersebut (baca: syariat, tarekat, hakikat, dan makrifat) merupakan satu kesatuan yang tidak bisa dipisahkan satu dengan lainnya. Sebagaimana yang dianalogikan oleh Hamzah Fansuri mengenai keempat hal tersebut, keempatnya dianalogikan sebuah kapal, syariat adalah luas kapal, tarekat merupakan papan kapal, hakikat adalah isi kapal, dan makrifat adalah keuntungan dari kapal yang telah diberdayakan fungsinya. ${ }^{9}$

Allah adalah Wujud, yakni Wujud yang benar-benar Mutlak, tidak terikat oleh suatu ikatan apapun, Mutlak yang tidak ada bandingannya, Wujud yang tanpa syarat apapun, Wujud yang tidak memiliki rupa khusus, tidak memiliki definisi tertentu yang membatasinya, dan tidak memiliki ketentuan yang mengikat-Nya. Apabila Dia terikat oleh hal-hal tersebut di atas, Dia tidak benar-benar Mutlak, padahal pada kenyataannya Dia benar-benar Mutlak dan kemutlakan hakiki-Nya itulah yang membenarkan terjadinya perwujudan (tajallii) dalam semua manifestasi. ${ }^{10}$

Pengertian di atas yang menerangkan bahwa al-Haq tidak dibatasi oleh rupa, definisi, dan ketentuan yang mengikat, meskipun demikian Dia dapat berwujud dengan rupa $^{11}$ dan definisi ${ }^{12}$, akan tetapi perumpamaan dan pendefinisian tersebut tidak dapat

${ }^{9}$ Sangidu, Wachdatul Wujud Polemik Pemikiran Sufistik Hamzah Fanshuri dan Syamsuddin asSamatrani dengan Nuruddin ar-Raniri, (Yogyakarta: Gama Media, 2003), hlm. 48.

${ }^{10}$ Oman Fathurahman, Ithaaf Al-Dhaki Tafsir Wahdatul Wujud bagi Muslim Nusantara, (Bandung: Mizan, 2012), hlm. 132.

11 “... aku melihat Tuhanku dalam rupa pemuda yang sempurna...", lihat selengkapnya di Oman Fathurahman, Ithaaf Al-Dhaki Tafsir Wahdatul Wujud bagi Muslim Nusantara, (Bandung: Mizan, 2012), hlm. 132.

12 “... Tuhannya berada di antara dirinya dan arah kiblat...”, lihat selengkapnya di Oman Fathurahman, Ithaaf Al-Dhaki Tafsir Wahdatul Wujud bagi Muslim Nusantara, (Bandung: Mizan, 2012), hlm. 132. 
mengubah hakikat dari sifat-Nya semula. Karena sifat-Nya yang semula berupa zat tanpa rupa khusus dan tanpa definisi tertentu bahkan dalam keadaan sekarang tetap seperti keadaan sebelumnya. ${ }^{13}$ Konsep ini serupa dengan konsep tajalli (penampakan), pada hakikatnya Wujud yang benar-benar mutlak tersebut tunggal, sedangkan manifestasi dari Wujud Mutlak tersebut beragam.

Wujud itu adalah realitas, semua eksistensi berikut bagian tersembunyi darinya. Mengenai keberadaan Wujud sebagai realitas bagi semua eksistensi, dan jika yang dimaksud dengan realitas itu adalah bagian tersembunyi segala sesuatu, maka kata wa baattinuhaa merupakan sebuah penghubung penjelas. Semua realitas atau eksistensi (baik yang terlihat maupun tidak terlihat) tidak akan luput dari Wujud tersebut, hingga biji atom sekali pun. Hal ini terjadi karena semua realitas yang ada merupakan gambaran realitas dari aspek lahir Wujud Mutlak dan dengan Wujud tersebut semua realitas ada. Jadi, hal yang tidak mungkin jika realitas ada tanpa Wujud, karena pada dasarnya segala realitas merupakan perwujudan lahir dari Wujud tersebut. ${ }^{14}$

Dalam pandangannya, setiap yang ada memiliki dua wujuйd, wujuйd luar yang merupakan ard dan khalq yang mempunyai sifat kemakhlukan. Dan wujūud dalam yang merupakan jauhar dan haq yang mempunyai sifat ketuhanan. Dengan arti lain, setiap wujū̄d memiliki sifat kemakhlukan dan ketuhanan. Dari kedua sifat tersebut, sifat ketuhanan (jauhar dan haq) yang paling utama. ${ }^{15} \mathrm{Hal}$ ini karena sifat tersebut merupakan

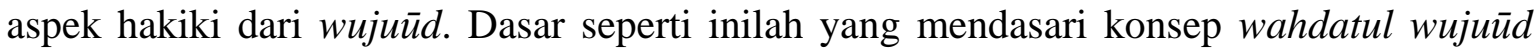

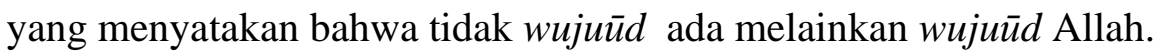

\section{b. Martabah Tujuh}

Martabah tujuh merupakan gagasan yang diusung oleh al-Buhanfuri dari India yang wafat pada tahun 1620. Pemahaman akan martabah tujuh memerlukan teori emanasi (tajalliyat). Maksudnya adalah sebagai bentuk penyingkapan zat Allah SWT, Allah menyingkapkan diri-Nya sendiri kepada seorang saalik. Tajalliyat atau penyingkapan ini tidak akan pernah berulang dengan bentuk yang sama dan juga tidak akan pernah berakhir. Bentuk penyingkapan-penyingkapan yang Allah tunjukkan berupa cahaya batiniah yang merasuk ke dalam hati hambanya. Proses ini merupakan sebagai tanda-tanda yang Allah berikan kepada hambanya agar dapat disaksikan olehnya. Akan tetapi, ketika Allah bertajalli kepada hambanya, dia akan tenggelam dalam keabadiannya.

\footnotetext{
${ }^{13}$ Lihat naskah at-Tuhfah al-Mursalah, hlm. 97.

${ }^{14}$ Lihat naskah at-Tuhfah al-Mursalah, hlm 99.

15 Aksin Wijaya dan Abu Bakar Yamani, Jejak Pemikiran Sufisme Indonesia Konsep Wujud dalam Tasawuf Shekh Yusuf al-Makassari, (Yogyakarta: Pustaka Ilmu, 2012), hlm. 40.
} 
Setiap orang akan mengalami bentuk tajalli yang berbeda, sehingga tidak akan ada dua orang atau lebih mengalami tajalli yang sama. Hanya orang pernah merasakan tajalli yang dapat mengetahuinya sedangkan mereka yang tidak pernah merasakan tajalli tidak akan pernah mengetahuinya. Tajalli menurut Sangidu melampaui ungkapan kata-kata sehingga sulit dibuktikan dengan logika. ${ }^{16}$ Tajalli adalah bentuk ketakjuban dan hanya dapat dicapai dengan zauq atau perasaan yang paling dalam. ${ }^{17}$

Wujū̄d Allah itu Esa dan merupakan hakikat semua bentuk makhluk. Semua eksistensi makhluk disebabkan oleh sendirinya, wujud semua eksistensinya adalah melaluinya, dan penolakan selain dirinya. Wujud Allah yang Mutlak dari segi Kunhi-Nya tidak akan tersingkap oleh siapa pun dan tidak akan terjangkau akal, angan-angan, dan perasaan. Kemudian, Wujud Mutlak-Nya tidak akan bisa dianalogikan oleh akal, anganangan, dan perasaan karena semuanya bersifat baru (muhdist). Hal ini karena semua yang baru tidak dapat mengetahui zat Allah kecuali zat dan sifat-Nya. dengan demikian apabila ada orang yang mempunyai keinginan untuk mengetahui wujūid Allah hanya melakukan pekerjaan yang sia-sia. ${ }^{18}$ Dalam proses penyelamaan spiritual menuju sang Khaliq, seorang saalik harus melewati tujuh tahapan martabah yaitu Martabah Laa Ta'ayyun, Martabah Ta'ayyun Awal, Martabah Ta'ayyun Thaanii, 'Aalam Al-'Arwaah\}, 'Aalam Al-Mithaal, 'Aalam Al-'Ajsaam, dan 'Aalam Al-'Insaan.

Syekh Hizboel Wathony menjelaskan bahwa martabah ketujuh adalah martabahnya para 'auliaa yang kaamil mukaamil yang telah mencapai maqam baqa' bilaah (kekal bersama Allah). ${ }^{19}$ Perilaku orang yang telah mencapai martabat ini akan berakhlak seperti akhlak Tuhan. Dia akan menjadi sosok manusia yang paripurna, memiliki kema'rifahan, dan kesempurnaan yang menjadikannya khalifah di muka bumi. Pandangan al-Buhanfuri mengatakan bahwa martabat Insaan kaamil ini terdapat pada diri Nabi Muhammad SAW, ${ }^{20}$ hal ini karena pada martabat ini merupakan pancaran (tajalli) Tuhan dalam dunia ini baru memperoleh kesempurnaannya dalam bentuk manusia. ${ }^{21}$

\footnotetext{
${ }^{16}$ Sangidu, Wachdatul Wujud Polemik Pemikiran Sufistik..., hlm. 55.

${ }^{17}$ Amatullah A, Khazanah Istilah Sufi: Kunci Memasuki Dunia Tasawuf. Cet. I, (Bandung: Mizan, 1996), hlm. 280.

${ }^{18}$ Lihat naskah C halaman 100.

${ }^{19}$ Ali. M. Abdillah, Tasawuf Kontemporer Nusantara Integrasi Tasawuf Ibn Arabi dan Al-Ghazali: Ajaran Tasawuf Syekh Hizboel Wathony Mursyid Tarekat Khalwatiyah Akmaliyah, (Jakarta: Ina Publikatama, 2011), hlm. 134.

${ }^{20}$ Lihat naskah at-Tuhfah al-Mursalah, halaman 106.

${ }^{21}$ Sangidu, Wachdatul Wujud Polemik Pemikiran Sufistik..., hlm. 68.
} 


\section{c. Insaan Kaamil}

Insaan Kaamil merupakan nama yang digunakan oleh para sufi untuk menamakan seorang muslim yang telah mencapai maqam tingkat tertinggi, yaitu tingkat seorang yang telah sampai pada fanaa fillaah. Setelah selesai membahas martabat tujuh, al-Buhanfuri memberikan kesimpulan sebagai berikut,

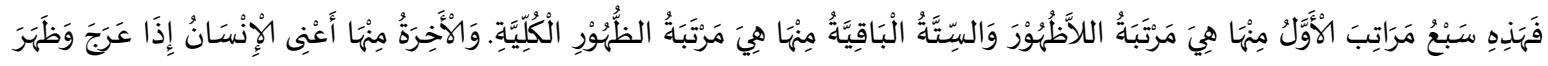

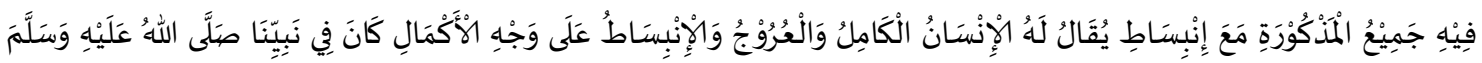
Artinya: "Maka semua ini ada tujuh martabat. Martabat pertama adalah martabat laa zuhuur (tidak nampak) sedangkan enam martabah lainnya martabah zuhuur (nampak) yang bersifat universal dan akhir maksudnya adalah al-Insaan. Apabila dia naik dan nampak dalam dirinya semua martabat tersebut serta dapat melampauinya, maka dia dinamakan al-“insaan al-kaamil (manusia yang sempurna).”

Menurut Ibn Arabi, pada manusia terhimpun rupa Tuhan dan rupa alam semesta. Dia adalah perwujudan Zat yang suci dengan segala sifat dan asma-Nya. dia adalah sebuah cermin di mana Tuhan menampakkan diri-Nya dan oleh karena itu manusia adalah penyebab terakhir dalam penciptaan. Dengan arti lain, manusia adalah gambaran Wujud Tuhan dan sebagai penjelmaan yang sempurna pada daya ciptaan-Nya. ${ }^{22}$ Adanya manusia adalah untuk menunjukkan akan kesempurnaan Tuhan dalam alam semesta dan untuk mencerminkan akan kebesarannya. Maka dari itu, manusia adalah manifestasi Wujud Allah.

Insaan kaamil menurut Ibn Arabi telah dijelaskan dalam kitabnya fusus, yaitu 'ain al-Haq artinya manusia adalah perwujudan dalam bentuk-Nya sendiri dengan segala keesaan-Nya. Berbeda dengan segala sesuatu yang lain, meskipun al-Haq (Tuhan) 'ain segala sesuatu, tetapi segala sesuatu bukan 'ain (zat)-Nya karena ia hanya perwujudan sebagian asma-Nya. Bukan Tuhan bertajalli pada sesuatu itu dalam bentuk Zat-Nya. Dan maksud dari al-insaan al-kaamil adalah kaamil dalam kemanusiaannya, yaitu Tuhan bertajalli dalam bentuk zat-Nya sendiri, itulah yang disebut dengan 'ainnya. ${ }^{23}$

Al-insaan al-kaamil ini tidak akan lepas kaitannya dengan konsep Nuur Muhammad. Ahmad Mahmud Subhi mengutarakan sebagaimana yang dikutip Asmaran bahwa yang dimaksud al-insaan al-kaamil bukanlah kecuali Nuur Muhammad.yaitu roh Ilahi yang Dia tiupkan kepada Adam. Kemudian dikatakan juga bahwa Nabi Muhammad adalah Nuur

\footnotetext{
${ }^{22}$ Asmaran, Pengantar Studi Tasawuf, (Jakarta: Raja Grafindo Persada 1994), hlm 344.

${ }^{23}$ Asmaran, Pengantar Studi..., hlm 347.
} 
Muhammad.yang paling sempurna, akan tetapi yang dimaksud di sini adalah al-haqiiqah al-muhammadiyyah. Dan dengan inilah orang bisa mencapai derajat al-insaan al-kaamil. ${ }^{24}$ Untuk mencapai derajat, seorang saalik harus melalui jalan fana dan baqa. Fana berarti dia sirna, menyatu, dan tenggelam dalam Wujud Tuhan sehingga dia menjadi satu denganNya. Sedangkan baqa berarti ketika dia sudah satu dengan wujud-Nya, maka yang tersisa dan dalam segala pandangannya adalah Wujud Tuhan.

Dalam beberapa keterangan dijelaskan bahwa konsep al-insaan al-kaamil berawal dari penciptaan makhluk pertama, yaitu Nuur Muhammad. Nuur Muhammad ini terpancar kepada semua maujudaat di alam semesta, manusia, hewan, benda mati, planet, dan lainnya. Akan tetapi, Nuur Muhammad yang ada pada diri manusia lebih sempurna. Ada pengkhususan lagi yaitu Nuur Muhammad pada diri nabi dan rasul lebih sempurna dari manusia lainnya. Dari sekian banyak nabi dan rasul yang Allah turunkan, $N u>r$ Muhammad pada 25 nabi dan rasul yang wajib diketahui lebih sempurna dari nabi dan rasul lainnya. Tantangan dan cobaan setiap nabi dan rasul berbeda satu dengan lainnya, dari 25 nabi dan rasul yang wajib diketahui ada 5 nabi dan rasul yang diberikan tantangan dan cobaan yang berat namun memiliki kesabaran dan tawakal yang lebih tinggi dari lainnya, dikenal dengan sebutan ulul azmi (Nabi Muhammad SAW., Nabi Ibrahim, Nabi Musa, Nabi Isa, dan Nabi Nuh). Kelima nabi dan rasul tersebut memiliki Nuur Muhammad yang lebih sempurna dari 25 nabi dan rasul lainnya. Dari semua makhluk, nabi, dan rasul yang Allah ciptakan, hanya ada satu makhluk di dunia ini yang memiliki Nuur Muhammad paling sempurna, yaitu Nabi Muhammad SAW.. Hal ini senada dengan firman Allah SWT.,

$$
\text { وَ إِنَّكَ لَعَلَى خُلْقِ عَظِيْمٍ }
$$

Artinya: " Dan sesungguhnya kamu benar-benar berbudi pekerti yang agung.,"25

Ditambah lagi dengan budi pekerti dan akhlak Nabi Muhammad SAW. yang menggambarkan kandungan al-Qur'an, wa kaana khuluquhu al-Qur'an. Sehingga Nabi Muhammad SAW. menjadi manusia paripurna di antara makhluk lainnya. Konsep manusia sempurna lebih jauh diutarakan dalam konteks manifestasi manusia yang khas. Manusia sempurna adalah individu manusia yang secara sempurna telah mewujudkan potensi spiritual penuh dari kemanusiaannya, yang telah mewujudkan dalam diri dan pengalamannya Kesatuan Wujud, yang mendasari semua keragaman nyata dari eksistensi. Mengenai manusia sempurna ini, Jalaluddin Rumi memberikan dua kriteria untuk menjadi

\footnotetext{
${ }^{24}$ Ahmad Mahmud Subhi dalam Asmaran, Pengantar Studi..., hlm 347.

${ }^{25}$ Q. S. Al-Qalam: 4.
} 
manusia sempurna, yaitu: pertama, dia harus berdiri dengan kakinya sendiri. Maksudnya adalah dia harus memiliki jiwa yang matang, pikiran yang jernih, dan optimisme yang tinggi. Hingga tidak ada keinginan untuk merepotkan dan menggantungkan hidupnya kepada orang lain, malahan dia ingin menjadi orang yang bermanfaat bagi orang lain. Kedua, dia harus memiliki tujuan hidup yang jelas. Merencanakan, mengetahui, dan memahami cara menjalani hidup dan kehidupan. Dia mempunyai visi dan misi ke depan yang jelas, yang berlandaskan pada tujuan akhir yaitu mencari sesuatu yang transendental. ${ }^{26}$

\section{Tasawuf: Kesalihan Individual dan Sosial}

Tasawuf merupakan sebuah disiplin ilmu yang dipandang lebih banyak berbicara tentang persalan- persoalan batin, kondisi- kondisi rohani dan hal- hal lain yang bersifat esoteris. Pengalaman- pengalaman yang dibentuk melalui proses implementasi ajaran sufistik bersifat mistik dan hampir mengarah ke dalam hal yang bersifat pribadi serta sulit dikomunikasikan kepada orang lain. Sehingga selamanya hampir menjadi milik pribadi. Pada perkembangannya, beragam tingkah laku aneh dan terkadang terkesan keluar dari batasan syar'i bermunculan, akan tetapi hal itu dipahami oleh kaum sufi sebagai bentuk pencapaian suatu maqam sufi tertentu.

Ibnu Taimiyyah berpandangan bahwa secara substansi ontologi tasawuf adalah agama Islam itu sendiri, sedangkan dalam metodologinya sebagai hasil ijtihad. Oleh karena itu, praktek- praktek tasawuf hanya dapat dibenarkan apabila bersumber dari al- Quran dan as- Sunah. ${ }^{27}$ Pada awalnya, ritual kesufian yang dilakukan adalah perilaku dan sikap zuhud yang diwarnai sikap mental tidak terperdaya oleh dunia, dan pelakunya disebut zahid. Seiring berkembangnya pengetahuan, konsep- konsep dalam tasawuf mengalami perkembangan fokus kajiannya, seperti adanya topik maqaam, fana, 'ahwaal, baqaa, ma'rifah, ittihaad, huluul, dan sebagainya, sehingga pelakunya bukan lagi zaahid melainkan sufi. Semua proses ritual sufi dilalui sebagai usaha untuk mengenal dirinya sendiri, dengan tujuan akhir adalah mengenal Tuhannya. Maqaamat dilalui dan ahwaal dirasakan sebagai bentuk penyucian batin dalam rangka menaikkan diri kepada entitas Tuhan. Karena apabila seorang hamba dapat mengenali, mengetahui, dan memahami hakikat dirinya maka dia akan mengenal Hakikat Allah. Sehingga, ketika dia kembali kesadaran dirinya sendiri, semua yang dia lihat di duni lahir adalah hakikat Allah. Semua

${ }^{26}$ Mukti Ali el-Qum, Spirit Islam Sufistik Tasawf Sebagai Instrumen Pembacaan Terhadap Islam, (Bekasi: Pustaka Isfahan, 2011), hlm.144-145.

27 Masyharuddin, Pemberontakan Tasawuf Kritik Ibn Taimiyah Atas Rancang Bangun Tasawuf, (JP Books: Surabaya, 2007), hlm. 268. 
sikap dan ritual tawasufnya mengalami perpindahan orientasi dari jiwa tetapi ke fisik, dari ruhani ke jismani, dari meditasi ke tindakan nyata, dan dari nilai pasif ke nilai aktif. ${ }^{28}$ Menurut Ali Sami al- Nasysyar dalam Masyharuddin berpandangan bahwa tasawuf sebuah fenomena yang lahir dan tumbuh bersifat lokalitas dan temporal, dengan artian tasawuf lahir dalam struktur masyarakat dan terpaut dengan fenomena- fenomena sosial lainnya, seperti agama, tradisi, adat istiadat, bahkan aktifitas ekonomi. Bahkan oleh para ahli sosiolog, tasawuf memiliki ciri- ciri, struktur, bahasa, dan simbol yang berbeda dengan lainnya. $^{29}$ Mengingat hal tersebut, tasawuf tidak dapat dipisahkan dari pengalaman keagamaan atau spiritual seseorang. Fenomena keagamaan meliputi dua hal, yaitu agama (ad-diin) dan pelaksanaan keagamaan atau keberagamaan (at-tadayyun). Adapun substansi keduanya berbeda, agama (ad-diin) sebagai rangkaian wahyu Tuhan yang harus dijadikan pedoman hidup bagi pemeluknya, sedangkan keberagamaan (at-tadayyun) merupakan usaha pemeluk agama dalam memandang, memposisikan, dan merespon ajaran agama sebagai pandangan, prinsip, pedoman, dan acuan hidup. Dan tasawuf adalah bentuk keberagamaan atau pengalaman keagamaan, keberagamaan dalam pemikiran, perbuatan, dan pergaulan.

Sebagaimana yang telah dipaparkan di pendahuluan, tasawuf merupakan salah satu jalan untuk mencapai kesalehan individual dan sosial. Meskipun pada umumnya praktek tasawuf lebih menekankan pada kesucian rohani manusia sebagai upaya untuk mendekatkan diri dan atau bersatu dengan Tuhan. Namun lebih luasnya, tasawuf merupakan sebuah cara untuk mensucikan diri secara individu sehingga terbentuklah individu yang shaleh, kemudian kesalehan tasawuf individu sufi diimplementasikan dalam kehidupan bermasyarakat untuk menciptakan keharmonisan dan menyelesaikan problematika sosial. Hal ini senada dengan senada dengan misi utama Rasul (sebagai alInsaan al-Kaamil) diutus ke muka bumi untuk menyempurnakan akhlak, akhlak yang mulia akan lahir dari diri seorang hamba yang suci dan akan memberikan dampak positif bagi lingkungannya. Ini lah bentuk reorientasi nilai individu-transedental tasawuf menuju nilai sosio-empirik yang dapat menyelesaikan berbagai permasalahan, baik itu permasalahan ekonomi, politik, sosial, dan sebagainya. 


\section{Kesimpulan}

Manusia merupakan salah satu bagian yang paling mulia dari makrokosmos (alam besar). Hal ini karena semua maujuudaat yang ada di alam besar telah ada dalam dirinya sebagai mikrokosmos (alam kecil). Al-insaan al-kaamil merupakan nilai- nilai tasawuf lebih menitikberatkan pada individual-transedental atau kesalehan individual dengan berpegang pada wahyu-wahyu Tuhan yang tidak dapat diganggu gugat dan besifat tunggal untuk meningkatkan kadar spritual dengan cara melewati semua maqamaat dan ahwaal, sehingga seorang sufi dapat menghayati eksistensi Tuhan. Keadaan orientasi tasawuf dari individual-transedental, dapat digeserkan kepada orientasi yang bersifat sosial-empirik (memberikan aksi nyata berupa kesalihan sosial sebagai bentuk tanggung jawab sosial dari tasawuf). Hal ini karena pada masa kini tasawuf dituntut melakukan reorientasi dan tanggungjawab tidak hanya pada kesalihan individual, akan tetapi lebih jauh lagi pada kesalihan sosial sebagai bentuk perubahan dari jiwa kepada fisik, ruhani kepada jasmani, meditasi kepada tindakan nyata, dan dari nilai pasif kepada nilai aktif.

\section{E. Daftar Pustaka}

A Amatullah. 1996. Khazanah Istilah Sufi: Kunci Memasuki Dunia Tasawuf. Cet. I. Bandung: Mizan.

Ali el-Qum, Mukti. 2011. Spirit Islam Sufistik Tasawf Sebagai Instrumen Pembacaan Terhadap Islam. Bekasi: Pustaka Isfahan.

Asmaran. 1994. Pengantar Studi Tasawuf. Jakarta: Raja Grafindo Persada.

Baried, Siti Baroroh. 1985. Pengantar Teori Filologi. Yogyakarta: Badan Penelitian dan Publikasi, Seksi Filologi, Fakultas Sastra Universitas Gadjah Mada.

Basuni, Ibrahim. 1919. Nasy'ah al- Tasawuf al- Islami. Mesir: Dar al- Ma'arif, Daulay, Saleh Partaonan. 2011. Taj 'al-Salaam Karya Bukhari Al-Jauhar Sebuah Kajian Filologi dan Refleksi Filosofis. Jakarta: Puslitbang Lektur dan Khazanah Keagamaan Badan Litbang dan Diklat.

Fathurahman, Oman. 2012. Ithaaf Al-Dhaaki Tafsir Wahdatul Wujud bagi Muslim Nusantara. Bandung: Mizan.

Hajjaj, Muhammad Fauqi. 2011. At-Tasawwuf Al-Islaami wal akhlaq. terj. Kamran As'at Irsyady dan Fakhri Ghazali. Jakarta: Amzah.

Khoiri, Alwan. 2014. Integrasi Pengamalan Syari'ah dan Tasawuf. Pascasarjana UIN Sunan Kalijaga. 
Lubis, Nabilah. 1996. Naskah, Teks, dan Metode Penelitian Filologi. Jakarta: Forum Kajian Bahasa \& Sastra Arab.

M. Abdillah, Ali. 2011. Tasawuf Kontemporer Nusantara Integrasi Tasawuf Ibn Arabi dan Al-Ghazali: Ajaran Tasawuf Syekh Hizboel Wathony Mursyid Tarekat Khalwatiyah Akmaliyah. Jakarta: Ina Publikatama.

Masrukhin, Muhammad Yunus. 2015. Biografi Ibn Arabi Perjalanan Spiritual Mencari Tuhan bersama Para Sufi. Depok: Keira Publishing.

Masyharuddin. 2007. Pemberontakan Tasawuf Kritik Ibn Taimiyah Atas Rancang Bangun Tasawuf. P Books: Surabaya.

Partanto Pius A. dan M. Dahlan A.. Tanpa tahun. Kamus Ilmiah Populer. Surabaya: Arkola.

Rahman, Dadang Abdu. 2003. Pengantar Metode Penelitian. Yogyakarta: Kurnia Kalam Semesta.

Ratna, Nyoman Kutha. 2004. Teori, Metode, dan Teknik Penelitian Sastra. Yogyakarta: Pustaka Pelajar.

Rusli, Ris'an. 2013. Tasawuf dan Tarekat Studi Pemikiran dan Pengalaman Sufi. Jakarta: Rajawali Press. Basuni, Ibrahim. 1919. Nasy'ah al- Tasawuf al-Islami. Mesir: Dar al- Ma'arif.

Sangidu. 2003. Wachdatul Wujud Polemik Pemikiran Sufistik Hamzah Fanshuri dan Syamsuddin as-Samatrani dengan Nuruddin ar-Raniri. Yogyakarta: Gama Media.

Sheikh, M. Saeed. 2016. Rekonstruksi Pemikiran Religius dalam Islam. Bandung: Mizan.

Tahzeh, Ahmad. 2009. Pengantar Metode Penelitian. Yogyakarta: Teras.

Wijaya, Aksin. dan Abu Bakar Yamani. 2012. Jejak Pemikiran Sufisme Indonesia Konsep Wujud dalam Tasawuf Shekh Yusuf al-Makassari. Yogyakarta: Pustaka Ilmu.

Zahri, Mustafa. 1995. Kunci Memahami Ilmu Tasawuf. Surabaya: Bina Ilmu. 
